\title{
Influence of Lagoons Size and Prey Availability on the Wading Birds (Ciconiiformes) in the Upper Paraná River Floodplain, Brazil
}

\author{
Márcio Rodrigo Gimenes ${ }^{1 *}$ and Luiz dos Anjos ${ }^{2}$ \\ ${ }^{l}$ Programa de Pós-Graduação em Ecologia de Ambientes Aquáticos Continentais; Universidade Estadual de \\ Maringá; Av. Colombo, 5790; mrgimenes@hotmail.com; 87020-900; Maringá - PR - Brasil. ${ }^{2}$ Departamento de \\ Biologia Animal e Vegetal; Universidade Estadual de Londrina; C. P. 6001; llanjos@sercomtel.com.br; \\ 86051-970; Londrina - PR - Brasil
}

\begin{abstract}
The influence of lagoons size and prey availability on the Ciconiiformes in the upper Parana river floodplain, Brazil, were analysed. The Ciconiiformes census was conducted quarterly in 2002, simultaneously to the fish census (gill nets and seining nets). There was strong relationship between the lagoons size and birds abundance, but modest relationship of lagoons size with the birds diversity and number of species. The presence of Ciconiiformes in the lagoons was better predicted by the fish density in seining nets than by the fish capture by unit of effort in gill nets. Except in the flood, there was strong relationship between the fishes density and birds relative abundance, and more modest relationship of the fishes density with birds diversity and number of species. The lagoon's size and prey availability were strong predictors of Ciconiiformes abundance and relative abundance, respectively. However, environmental variables not analysed probably could have significant influence in the determination of the birds diversity and number of species.
\end{abstract}

Key words: Wading birds, Ciconiiformes, prey availability, lagoons, Paraná river

\section{INTRODUCTION}

For the birds that feed and breed on them, lagoons are hospitable islands of water surrounded by reasonably inhospitable habitats. Thus, one of the important points of conservation biology, the relationship between the area and diversity, abundance and number of species, has been examined for birds that use lagoons (Elmberg et al., 1993; Paszkowski and Tonn, 2000). However, in some cases, the perimeter of the lagoon has been better predictor than the area for the diversity, abundance and number of species of aquatic birds, mainly in situations where the feeding is restricted to the periphery of the lagoon (Elmberg et al., 1994; Suter, 1994), as in the case of Ciconiiformes foraging at deep lagoons.

There are several studies analyzing habitat use by Ciconiiformes (Custer and Osborn, 1978; Erwin, 1983; Powell, 1987; Smith and Breininger, 1995; Gaines et al., 1998; Maccarone and Brzorad, 1998; Gaines et al., 2000; Wong et al., 2001), and the spatial and temporal population fluctuations are frequently attributed to the food availability (Erwin, 1983; González, 1996; Young and Chan, 1997; Gaines et al., 1998; Butler and Vennesland, 2000). However, there are few studies conducted in natural habitats where there is a quantification

*Author for correspondence 
of the prey availability (Kushlan, 1976b; Caldwell, 1986; Master et al., 1993; Smith, 1997; Battley et al., 2003), mainly in tropical areas. In addition, great part of Ciconiiformes has fish as the main food item (Del Hoyo et al., 1992), very mobile animals that hinder the quantification of the actual available preys, because not all the individuals are vulnerable to predation. This fact is quite accentuated in floodplains, where variations in the hydrometric level constantly alter space-temporally the vulnerability of the fishes (Gawlik, 2002).

The Paraná river, ranking tenth in discharge in the world, and fourth in drainage area $\left(5 \times 10^{8}\right.$ $\mathrm{m}^{3} /$ year; $2.8 \times 10^{6} \mathrm{~km}^{2}$, respectively), is approximately $4695 \mathrm{~km}$ long and drain all the south-central part of South America (Agostinho et al., 1995). The Paraná river basin has suffered strong human impact, mainly deforestation and dams building. The $230-\mathrm{km}$ river stretch between the mouth of the Paranapanema river (its main affluent) and the town of Guaíra PR, Brazil, in the upper Paraná river is the only significant segment within Brazilian territory which is free from dams (Agostinho et al., 1994). Although the upstream dammings has altered the natural river regime (flooded of November to May and drought of June to October), the flood pulse is the principal factor that acts on the communities of area (Thomaz et al., 1997). On the left bank (Paraná State) of this stretch of the river, with a reasonable land elevation, there are restricted flooded areas and semideciduous forests have almost all been transformed into pasture lands. On the right bank (Mato Grosso do Sul State), with low land elevation, there is a fairly well preserved floodplain where numerous secondary channels, lagoons, and rivers are braided (Souza-Filho and Stevaux, 1997). The presence of several lagoons in that floodplain offers the opportunity to evaluate, in a natural habitat, the influence of lagoons size and prey availability on the Ciconiiformes community.

This study analyzed the influence of lagoon's area and perimeter as predictors of the Ciconiiformes diversity, abundance, and number of species. It also analyzed whether Ciconiiformes diversity, relative abundance, and number of species were associated to the prey availability in the lagoons. It was the first study analyzing the Ciconiiformes community in the region.

\section{MATERIALS AND METHODS}

\section{Study area}

The studied stretch lie in the upper Paraná river floodplain $\left(22^{\circ} 40^{\prime} \mathrm{S}\right.$ to $22^{\circ} 52^{\prime} \mathrm{S}$ and $53^{\circ} 12^{\prime} \mathrm{W}$ to $53^{\circ} 38^{\prime} \mathrm{W}$ ), at an altitude of $230 \mathrm{~m}$ a.s.l. (Maack, 1981). According to the Köeppen's system, the region's climate is classified as Cfa (tropicalsubtropical) with an average annual temperature of $22^{\circ} \mathrm{C}$ (summer average $26^{\circ} \mathrm{C}$, and winter average $19^{\circ} \mathrm{C}$ ) and an average annual rainfall of $1500 \mathrm{~mm}$ (Centrais Elétricas do Sul do Brasil, 1986). The hydrometric level of Paraná river in this region was higher between middle-January and April 2002, with several short-duration flood pulses (Fig. 1).

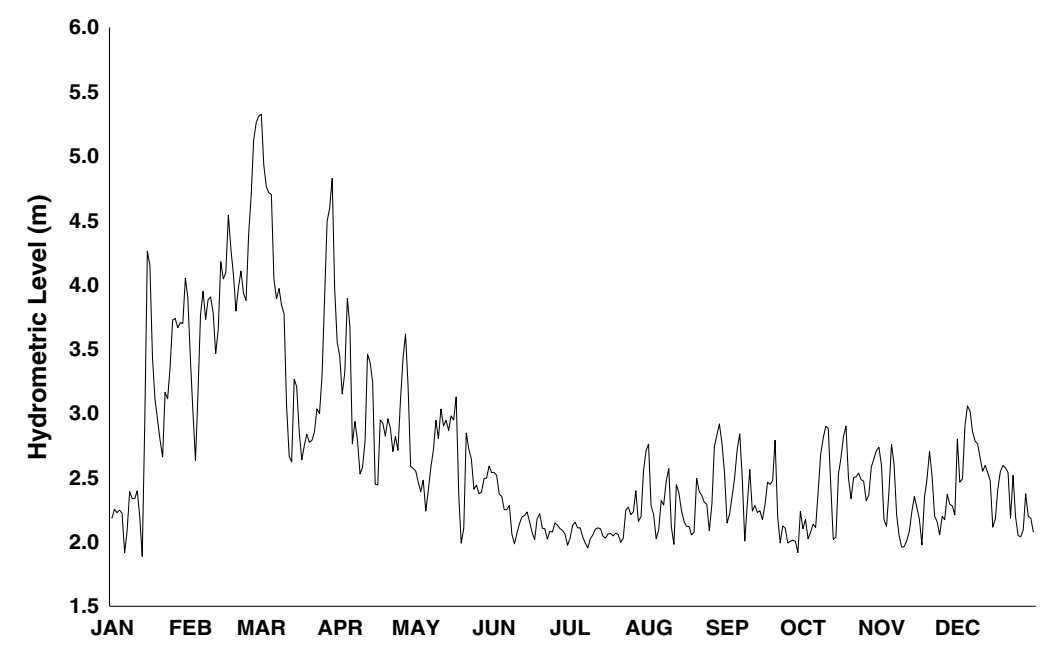

Figure 1 - Hydrometric level of upper Paraná river in the study area at 2002. Data obtained from Porto São José Hydrometric Station. 
The floodplain lie within the phytoecological region of semideciduous seasonal forest, being the non-forests areas characterized by fields, pastures, shrubs, swamps, "várzeas", and permanent or temporary water bodies, with the presence of "Cerrado" and "Chaco" plant species in some areas (Campos and Souza, 1997).

Sixteen open lagoons (constantly connected to the rivers or channels), whose areas reached from 0.66 to 113.8 ha and the perimeters from 0.489 to $14.783 \mathrm{~km}$ (Table 1), were included in this study (Fig. 2). The average depth was from $1.3 \mathrm{~m}$ to 3.6 $m$ (Souza-Filho and Stevaux, 2002) and the margins slopes were such that only the periphery was shallow enough to allow the presence of Ciconiiformes. The bottom sediment varied from sand-gravel to clay with accumulation of organic matter (Stevaux et al., 1997). Different proportions of these lagoons were occupied by free-floating plants (Eichhornia crassipes and Salvinia auriculata), rooted plants (Eichhornia azurea and Polygonum acuminatum) and submerged ones (Utricullaria spp and Cabomba spp). The surrounding landscape was without any vegetation, covered by the "várzea" (Panicum prionitis, Paspalum conspersum, Eleocharis spp and Fimbristylis autumnalis) or by the forests (Cecropia pachystachya, Croton urucurana, Inga vera, Peschiera australis and others) (Souza et al., 1997), being from droughts until completely flooded, according to the phase of the Paraná river regime. Additional informations on the study area are in Vazzoler et al. (1997a) and the detailed description of each studied lagoon is in SouzaFilho and Stevaux (2002).

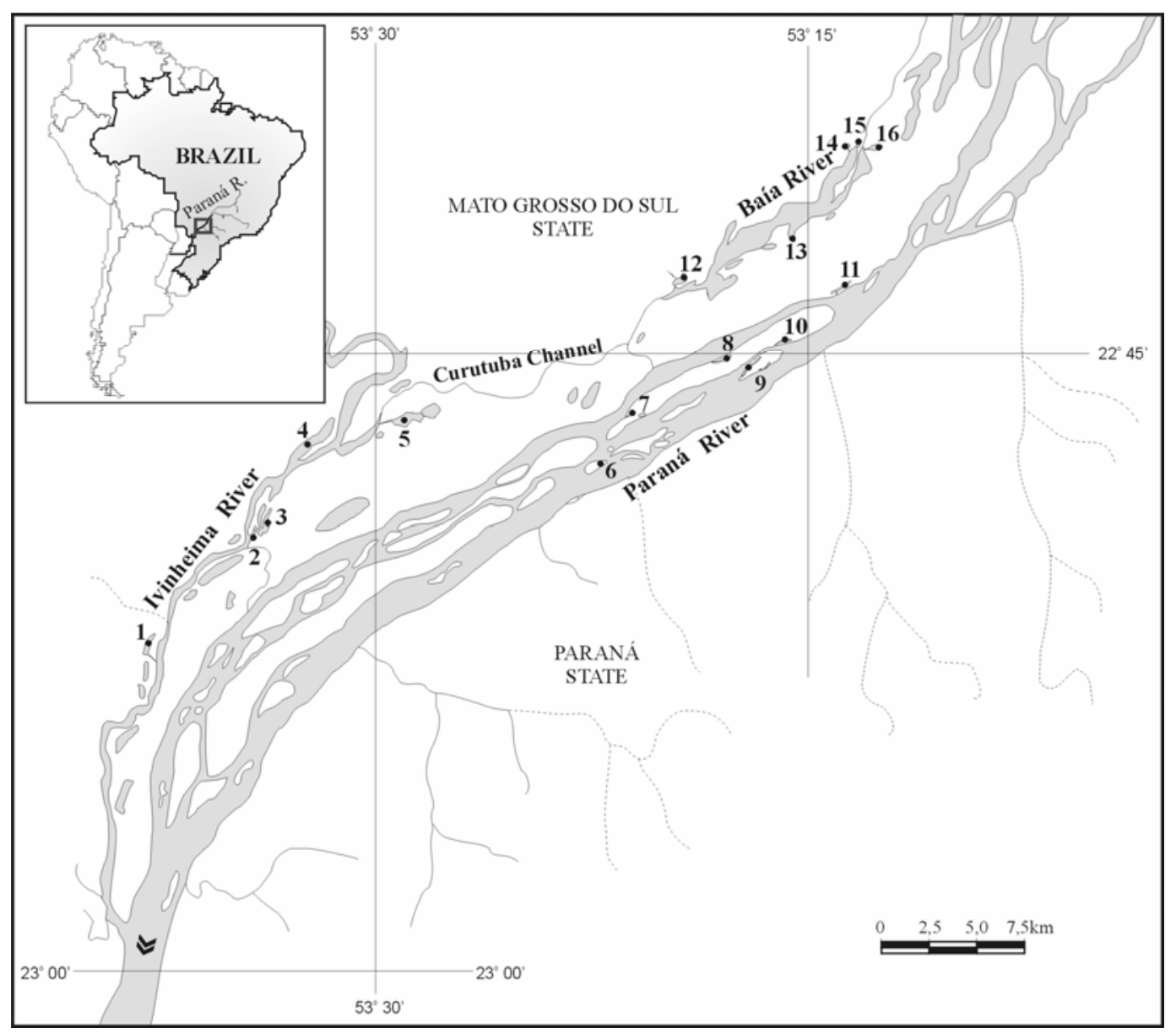

Figure 2 - Upper Paraná river floodplain with the studied lagoons: 1-Peroba, 2-Boca do Ipoitã, 3-Patos, 4-Finado Raimundo, 5-Sumida, 6-Pombas, 7-Manezinho, 8-Bilé, 9-Leopoldo, 10-Pau-Véio, 11-Garças, 12-Guaraná, 13-Porcos, 14-Maria Luiza, 15-Gavião and 16Onça. 


\section{Methods}

The Ciconiiformes censuses were conducted in February, May, August and November 2002. In every month, a sampling and a repetition were conducted on each lagoon, always beginning one hour after sunrise. The sampling method was the transect with aid of a boat (according to Bibby et al., 1992), with which the lagoons were internally surrounded and each sighted bird was identified and registered. Individuals registered in a strip of even about $5 \mathrm{~m}$ out of the lagoons were included, but not those registered flying, unless were observed leaving from the lagoon or landing in it. The mean annual abundance in each lagoon (mean number of individuals) was obtained by adding the total number of individuals in the lagoon and dividing by the number of samplings conducted (eigth). The diversity in each lagoon was estimated by the use of the Shannon's Diversity Index (Magurran, 1988). The relative abundance of Ciconiiformes in each lagoon at each of four months of the year was obtained dividing the number of individuals registered in that period (mean between sampling and repetition) by the best predictor (area or perimeter) of the diversity, number of species and mean annual abundance in the lagoons. The taxonomy, nomenclature and common names of the species were according to CBRO (2005).

The prey census was limited only to the quantification of fishes and the data were obtained from the censuses of Long Duration Ecology Program (PELD/CNPq/NUPÉLIA) that conducted a monitoring of the ichthyofauna in the upper Paraná river floodplain since 2000. Birds and fishes samplings were conducted in annual concomitants periods. The lagoons were separated in two groups according to the fish sampling method used: seining nets (in the periphery of the lagoons) and gill nets (in deeper areas). The abundance in gill nets was expressed in capture by unit of effort (CPUE), in other words, number of individuals in $1000 \mathrm{~m}^{2}$ net in $24 \mathrm{~h}$, while the abundance in seining nets was expressed in density (number of individuals in $100 \mathrm{~m}^{2}$ net). Due to those different units, the results between the two groups of lagoons could not be analysed together. For the present study only were considered the fishes up to $30 \mathrm{~cm}$ long, approximately the maximum size captured by the largest Ciconiiformes species (Willard, 1985). Detailed informations of the fish samplings methods are in
Júlio Jr. et al. (2000). The area and perimeter of lagoons were obtained from aerial photos of September 1996 (Souza-Filho and Stevaux, 2002). The relationship of the diversity, mean annual abundance and total number of species of Ciconiiformes with the area and perimeter of the lagoons were calculated through the Pearson's Correlation Analysis. The area and perimeter values were logarithm-transformed to normalize the data. The same statistic test was used to estimate the relationship of the diversity, relative abundance and number of species of Ciconiiformes with the CPUE and density values of fish in each one of the four periods of the year in the studied lagoons. The variables that didn't present normal distribution were transformed (logarithm, when the variance very exceeded the mean and square root, when the variance was inferior or close to the mean) in order to obtain this presupposition. When the normalization was not reached, Spearman's Correlation Analysis was used. The results of the fish census in gill nets (CPUE) and seining nets (density) were analysed separately.

\section{RESULTS}

A total of 15 species of Ciconiiformes were registered in the upper Paraná river floodplain. The Whistling Heron (Syrigma sibilatrix), Capped Heron (Pilherodius pileatus), Cattle Egret (Bubulcus ibis) and Buff-necked Ibis (Theristicus caudatus) were not registered in the studied lagoons and were not included in the analyses. The Green Ibis (Mesembrinibis cayennensis) was excluded due to being not eater of fish (Del Hoyo et al., 1992; Frederick and Bildstein, 1992). Ten species (Cocoi heron, Ardea cocoi; Great Withe Egret, Ardea alba; Snowy Egret, Egretta thula; Green-backed Heron, Butorides striata; Blackcrowned Night-heron, Nycticorax nycticorax; Rufescent Tiger-heron, Tigrisoma lineatum; Wood Stork, Mycteria americana; Maguari Stork, Ciconia maguari; Jabiru, Jabiru mycteria and Roseate Spoonbill, Platalea ajaja), although consumed other preys, had fishes as fundamental item in their diets (Kushlan et al., 1985; Willard, 1985; Del Hoyo et al., 1992; González, 1997; Smith, 1997; Bryan and Gariboldi, 1998), and were analysed together for the purpose of this study.

The Shannon's Diversity Index, total number of 
species and mean annual abundance of Ciconiiformes in each lagoon are shown in the Table 1.

There was modest and very similar relationship of the Ciconiiformes diversity with the area and perimeter of the lagoons $(\mathrm{r}=0.55$ and $\mathrm{r}=0.53$, respectively; $\mathrm{n}=16 ; P<0.05)$. The relationship of the mean annual abundance with the area and perimeter was strong and identical $(\mathrm{r}=0.88 ; \mathrm{n}=$ 16; $P<0.001)$. Finally, the relationship of the number of species with the area was modest $(\mathrm{r}=$ $0.69 ; \mathrm{n}=16 ; P<0.01)$, although more relevant than with the perimeter $(\mathrm{r}=0.54 ; \mathrm{n}=16 ; P<0.05)$ (Fig. 3).

Table 1 - Studied lagoons indicating area, perimeter, Shannon's Diversity Index (H'), total number of species (NSP) and mean annual abundance (ABU \pm SE) of Ciconiiformes. In the lagoons marked with an asterisk $(*)$ was used seining nets and in the lagoons without asterisk gill nets.

\begin{tabular}{lccccc}
\multicolumn{1}{c}{ LAGOONS } & AREA (ha) & PERÍMETER $(\mathbf{k m})$ & H' & NSP & ABU ( \pm SE) \\
\hline Manezinho* & 0.66 & 0.489 & 0.27 & 2 & $0.37( \pm 0.26)$ \\
Bilé* $_{\text {Boca do Ipoitã }}^{*}$ & 1.96 & 1.195 & 0.51 & 4 & $3.25( \pm 1.01)$ \\
Gavião & 2.30 & 0.786 & 0.54 & 5 & $2.12( \pm 0.78)$ \\
Leopoldo* & 2.33 & 0.796 & 0.49 & 5 & $3.62( \pm 0.90)$ \\
Pau-Véio & 2.95 & 2.046 & 0.59 & 5 & $5.50( \pm 1.46)$ \\
Guaraná & 3.00 & 2.322 & 0.55 & 4 & $3.25( \pm 1.15)$ \\
Pombas* & 4.20 & 1.058 & 0.49 & 7 & $7.62( \pm 2.02)$ \\
Porcos* & 5.74 & 1.146 & 0.47 & 5 & $1.50( \pm 0.45)$ \\
Peroba & 6.20 & 1.823 & 0.69 & 6 & $9.12( \pm 0.80)$ \\
Garças & 12.20 & 1.980 & 0.73 & 6 & $3.00( \pm 0.88)$ \\
Maria Luiza* & 14.10 & 4.338 & 0.41 & 4 & $1.00( \pm 3.33)$ \\
Onça & 14.70 & 2.579 & 0.62 & 8 & $14.00( \pm 2.85)$ \\
Sumida & 27.20 & 3.746 & 0.71 & 7 & $14.87( \pm 2.70)$ \\
Finado Raimundo & 67.40 & 4.681 & 0.57 & 8 & $17.75( \pm 4.92)$ \\
Patos & 84.90 & 7.151 & 0.52 & 5 & $12.50( \pm 4.51)$ \\
\hline
\end{tabular}

Thus, the area was considered better predictor than the perimeter of number of species of Ciconiiformes and was adopted in the calculation of the relative abundance of Ciconiiformes in the lagoons. It was remarkable to note that excluding of the analyses Snowy Egret and Green-backed Heron, the two more abundant species, the perimeter became better predictor than the area of the diversity ( $\mathrm{r}=0.68$ and $\mathrm{r}=0.61$, respectively; $P$ $<0.05)$ and mean annual abundance $(\mathrm{r}=0.80$ and $\mathrm{r}$ $=0.76$, respectively; $P<0.01$ ); the relationship of the number of species with the perimeter approached that with the area, although it didn't surpass ( $\mathrm{r}=0.71$ and $\mathrm{r}=0.73$, respectively; $P<$ 0.05). A fortification of the relationship of the diversity and number of species with the size of the lagoons was also remarkable.

The correlation values of the Ciconiiformes diversity and number of species with the fish CPUE in gill nets were very weak and not significant in all studied months. The relative abundance of Ciconiiformes (number of individual/ha) was strong and significantly related to the fish in this net type only during November.
The fish density in seining nets seemed to have stronger influence on the Ciconiiformes community, mainly on the relative abundance of birds, since the relationship was strong and significant during May, August and November. The diversity and number of species were very strong and significantly related to the fish density in seining nets during August, but modest and not significantly in the other months. In a general way, there was very weak or not significant relationship of Ciconiiformes community with the amount of fish during February, with increase of this relationship mainly during August and November months that together presented five of the six significant correlation values (Table 2). 

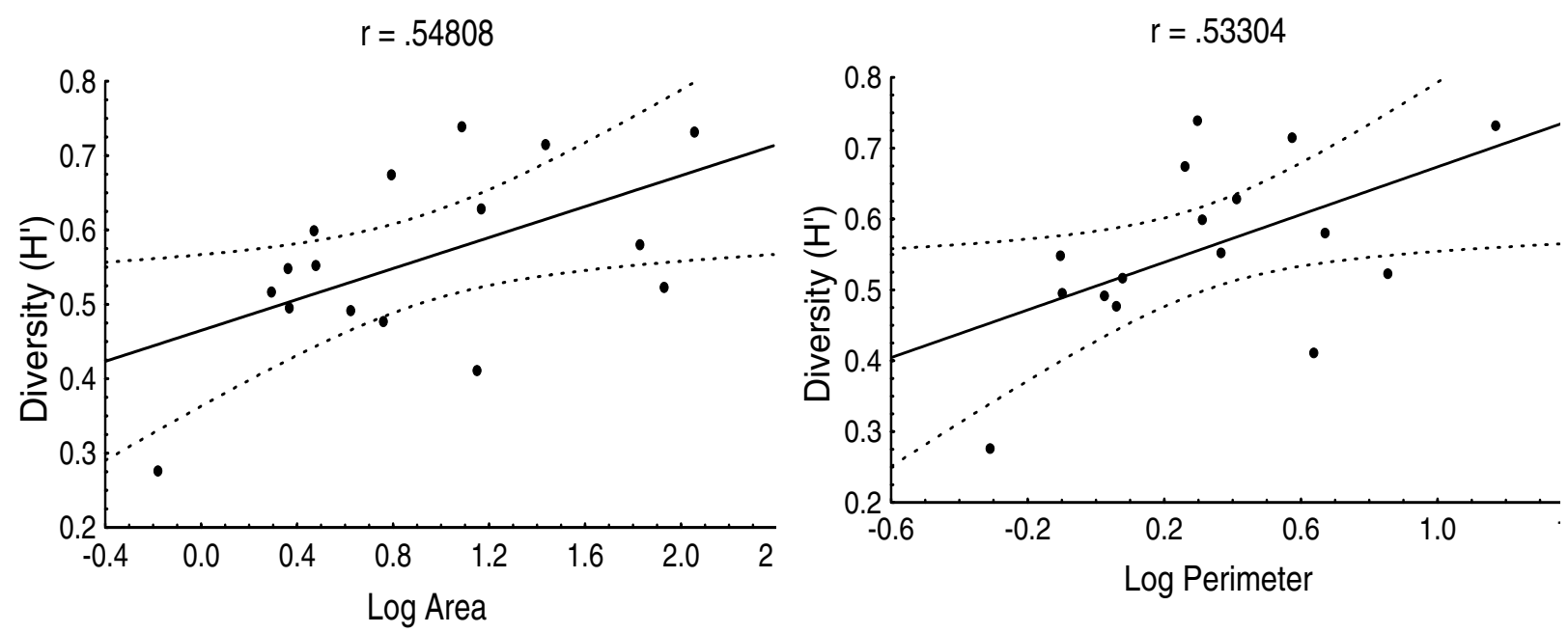

$r=.87608$
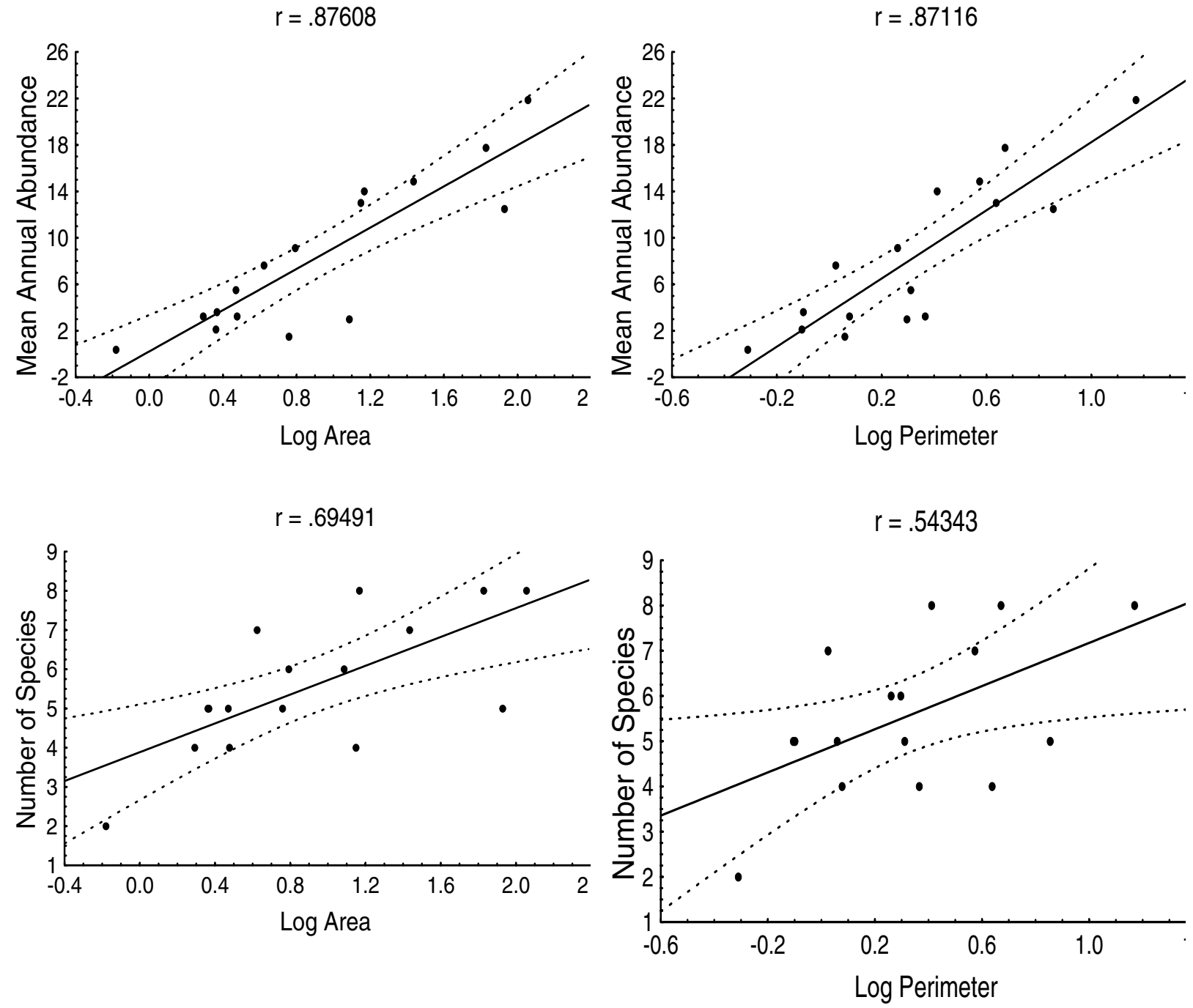

Figure 3 - Relationship of the area and perimeter of the 16 studied lagoons with the diversity, mean annual abundance and number of species of Ciconiiformes. 
Table 2 - Pearson's correlation coefficients of the fish CPUE in gill nets and fish density in seining nets with the diversity $\left(\mathrm{H}^{\prime}\right)$, relative abundance (REAB) and number of species (NSP) of Ciconiiformes in each month in the studied lagoons. The values in italic were obtained through the Spearman's Correlation Analysis.

\begin{tabular}{lcccccc}
\hline & \multicolumn{3}{c}{ GILL NETS } & \multicolumn{3}{c}{ SEINING NETS } \\
& $\mathrm{H}^{\prime}$ & REAB & NSP & H' & REAB & NSP \\
\hline FEBRUARY & -0.10 & -0.05 & 0.10 & 0.24 & 0.18 & 0.34 \\
MAY & -0.09 & 0.33 & 0.13 & 0.43 & $0.87^{* *}$ & 0.61 \\
AUGUST & 0.20 & 0.34 & 0.07 & $0.93^{* *}$ & $0.79^{*}$ & $0.96^{* * *}$ \\
NOVEMBER & 0.05 & $0.75^{*}$ & 0.29 & 0.57 & $0.81^{*}$ & 0.63 \\
\hline
\end{tabular}

Note: *Significant correlation in P < 0.05 ; **highly significant correlation in $\mathrm{P}<0.01$; *** very highly significant correlation in $\mathrm{P}<0.001$.

\section{DISCUSSION}

At first, it appeared surprising that the perimeter was not better predictor than the area of the Ciconiiformes diversity, mean annual abundance and number of species in the studied lagoons. In studies analyzing aquatic birds whose foraging is usually limited to the periphery in deep lagoons, due to a maximum threshold of depth where this activity is possible, has been verifying stronger relationship of these birds with the perimeter (Elmberg et al., 1994; Suter, 1994). Although some Ciconiiformes species presented techniques of aerial and swimming foraging that allowed them to explore deep areas in the lagoons (Kushlan, 1976a), what would tend to strengthen the relationship of these birds with the area, the fact was quite rare and was never observed in the study region.

However, Snowy Egret and Green-backed Heron, the two more abundant species in the study region, were frequently observed foraging on the dense surface mats of aquatic plants to provide support in deep water areas of the lagoons, which was also observed in other studies (Kushlan et al., 1985; Willard, 1985; Smith, 1997). As this aquatic plants mats cover great part of the lagoons sporadically, these species can explore an area of the lagoons surface quite beyond of periphery, strengthening the relationship with the area. The strengthening of the relationship of the perimeter with the Ciconiiformes diversity, mean annual abundance and number of species when the two species were excluded of the analyses corroborated this hypothesis.

In general, there was modest relationship between lagoons size and Ciconiiformes diversity, as well as between lagoons size and the number of species. Even in studies that verified strong relationship between the number of species and lagoons size, was evident that other factors interfered in the relationship, as the microhabitats variety, food availability and variety, and the presence of competitors (Elmberg et al., 1993; Paszkowski and Tonn, 2000). In the present study, the exclusion of Snowy Egret and Green-backed Heron of the analyses strengthened the relationship of the number of species and, consequently, of the diversity with the lagoons size. These species were the only registered foraging on the dense surface mats of aquatic plants in deep waters, a specific microhabitat whose occurrence depended not on the lagoons size and interfered in the relationship. The mean annual abundance of Ciconiiformes had strong relationship with the lagoons size, possibly due to the fact of the Ciconiiformes defend an individual territory around of them that can enlarge or contract according to the circumstances (Kushlan, 1978; Butler, 1994). Thus, the increase of lagoons size would make possible the inclusion of new individuals of the species that there forage.

It was clear that the Ciconiiformes diversity, number of species and relative abundance were more strongly related to the fish density in seining nets than to the fish CPUE in gill nets, where there was almost total lack of significant relationship. The seining nets capture fishes that inhabit the periphery of the lagoons, while the gill nets usually capture fishes that inhabit deeper areas, evidently less vulnerable to the predation for birds. According to Gawlik (2002), when referring to the prey availability is necessary not only the quantification of these, but also know to that point are its vulnerable to the predation. When the preys are fishes, very mobiles animals that evolved effective mechanisms to reduce the probability of predation, the vulnerability of these fishes in a certain habitat can be more important for the predator than the amount of individuals preys presents (Erwin, 1985).

The weak and no significant correlation values of 
the Ciconiiformes diversity, number of species and relative abundance with the fish density during February were probably associated to the hydrometric level of the floodplain. February corresponded to the flood period in the floodplain (Fig. 1) and in the most of the lagoons the transition area with the surrounding landscape was flooded, with depth levels above the threshold where the foraging of the Ciconiiformes was possible. In spite of the flood to be the period of highest fish productivity in floodplains (Loftus and Eklund, 1994; Vazzoler et al., 1997b), the fishes were more dispersed and less vulnerable to the birds due to the high connectivity among the water bodies. Thus, independent of the amount of fishes, the shortage of adequate habitats available and the low fish vulnerability turned this environment inhospitable for Ciconiiformes in the flood, a fact verified in flooded areas elsewhere also (Custer and Osborn, 1978; Erwin, 1983; Powell, 1987; Smith and Breininger, 1995; Custer et al., 1996; González, 1996; Strong et al., 1997; Russell et al., 2002). In the study area, only Green-backed Heron, capable to forage in deep waters, was abundant in this period.

In the other studied months, there was strong and significant relationship between the fishes density and relative abundance of Ciconiiformes. In this whole period, the hydrometric level was well lower than during February (Fig. 1), having more adequate foraging habitats available and, certainly, lower fish dispersion. It has been observed that for foraging optimization, the Ciconiiformes depend on habitat patches with adequate depth and high prey density (Kushlan, 1976b; Master et al., 1993; Russell et al., 2002; Battley et al., 2003). As these two characteristics are quite ephemeral in the floodplains, it is common to register high relative abundance of Ciconiiformes momentarily in adequate patches. When there happens a resource depression, the birds look by other high quality patches, what reflects the opportunist character of Ciconiiformes (Kushlan, 1981; Fasola, 1994). The relationship of the Ciconiiformes diversity and number of species with the fish density oscillated of modest and not significant to very strong and significant, possibly due to the presence of some species in certain lagoon to depend not only of the fish density, but also of the presence of specific microhabitats or prey types seasonably.

The strong and significant correlation values concentrated at the drought months (August and November) could be associated also to the breed cycle of the Ciconiiformes. Although there are no studies about the Ciconiiformes breeding in the region, possibly the most of the species breed in the drought period, as happens at the Pantanal Matogrossense (Willis, 1995). Adult birds raising nestlings face intense demands for food acquisition, needing to optimize its foraging efficiency and energy intake (Erwin, 1985). This can be facilitated foraging in the lagoons with more fish availability in the study area.

This study demonstrated that the lagoons size and fish availability in the studied lagoons were strong predictors of the abundance and relative abundance of Ciconiiformes, respectively. However, habitat variables not analysed in this study probably acted strongly in the determination of the Ciconiiformes diversity and number of species.

\section{ACKNOWLEDGEMENTS}

This study had the financial support of the Programa de Pós-Graduação em Ecologia de Ambientes Aquáticos Continentais (PEA) and the Núcleo de Pesquisas em Limnologia, Ictiologia e Aqüicultura (Nupélia) of the Universidade Estadual de Maringá. MRG received $\mathrm{PhD}$. Scholarship from CNPq-Brazil and LdA received a Research Productivity grant from $\mathrm{CNPq}$ (350054/95-9). Sebastião Rodrigues, Leandro Rodrigues and Alfredo da Silva helped in field work. Comments of Dr. Erivelto Goulart and Dra. Maria Conceição de Souza improved the manuscript.

\section{RESUMO}

Foi analisada a influência do tamanho das lagoas e da disponibilidade de presas sobre os Ciconiiformes na planície alagável do Alto Rio Paraná, Brasil. O censo dos Ciconiiformes foi realizado trimestralmente em 2002, concomitantemente às amostragens de peixes (redes de arrasto e redes de espera). Houve forte relação do tamanho das lagoas com a abundância média de aves no ano, mas modesta relação com a diversidade e o número de espécies. A densidade de peixes em redes de arrasto foi melhor prognosticadora dos Ciconiiformes do que as capturas por unidade de esforço em redes de 
espera. Exceto na cheia, houve forte relação da densidade de peixes com a abundância relativa de aves e mais modesta relação da densidade de peixes com a diversidade e número de espécies de aves. O tamanho das lagoas e a disponibilidade de presas foram fortes prognosticadores da abundância e abundância relativa de Ciconiiformes, respectivamente. Porém, variáveis ambientais aqui não analisadas podem ter influência significativa na determinação da diversidade e número de espécies de aves presentes.

\section{REFERENCES}

Agostinho, A. A.; Julio Jr., H. F. and Petrere, Jr., M. (1994), Itaipu reservoir (Brazil): impacts of the impoundment on the fish fauna and fisheries. In: Cowx, I. G. (Ed.). Rehabilitation of freshwater fisheries. Bodman: Fishing News Book. pp. 171-184.

Agostinho, A. A.; Vazzoler, A. E. A. M. and Thomaz, S. M. (1995), The high River Paraná Basin: limnological and ichtyological aspects. In: Tundisi, J. G.; Bicudo, C. E. M. and Matsumura-Tundisi, T. (Eds.). Limnology in Brazil. Rio de Janeiro: ABC/SBL. pp. 59-103.

Battley, P. F.; Poot, M.; Wiersma, P.; Gordon, C.; Ntiamoa-Baidu, Y. and Piersma, T. (2003), Social foraging by waterbirds in shallow coastal lagoons in Ghana. Waterbirds, 26 : (1), 26-34.

Bibby, C. J.; Burgess, N. D. and Hill, D. A. (1992), Bird census techniques. London: Academic Press.

Bryan Jr., A. L. and Gariboldi, J. C. (1998), Food of nestling wood storks in coastal Georgia. Colon. Waterbirds, 21 : (2), 152-158.

Butler, R. W. (1994), Population regulation of wading Ciconiiform birds. Colon. Waterbirds, 17 : (2), 189-199.

Butler, R. W. and Vennesland, R. G. (2000), Integrating climate change and predation risk with wading bird conservation research in North America. Waterbirds, 23 : (3), 535-540.

Caldwell, G. S. (1986), Predation as a selective force on foraging herons: effects of plumage color and flocking. Auk, 103, 494-505.

Campos, J. B. and Souza, M. C. (1997), Vegetação. In: Vazzoler, A. E. A. M.; Agostinho, A. A. and Hahn, N. S. (Eds.). A planície de inundação do alto rio Paraná: aspectos físicos, biológicos e socioeconômicos. Maringá: EDUEM. pp. 331-342.

CBRO (2005), Lista das aves do Brasil. Versão 1/2/2005. Disponível em: http://www.ib.usp.br/cbro. Acesso em: 9 mar. 2005.
Centrais Elétricas do Sul do Brasil (1986), Ilha Grande. Relatório de pesquisa. Florianópolis: ELETROSUL. v. 4.

Custer, T. W. and Osborn, R. G. (1978), Feeding habitat use by colonially-breeding herons, egrets, and ibises in north Carolina. Auk, 95, 733-743.

Custer, T. W.; Hines, R. K. and Custer, C. M. (1996), Nest initiation and clutch size of great blue herons on the Mississippi river in relation to the 1993 flood. Condor, 98, 181-188.

Del Hoyo, J.; Elliott, A. and Sargatal, J. (1992), Handbook of the birds of the world. Barcelona: Copyright Lynx Edicions. v. 1.

Elmberg, J.; Nummi, P.; Poysa, H. and Sjoberg, K. (1993), Factors affecting species number and density of dabbling duck guilds in North Europe. Ecography, 16, 251-260.

Elmberg, J.; Nummi, P.; Poysa, H. and Sjoberg, K. (1994), Relationships between species number, lake size and resource diversity in assemblages of breeding waterfowl. J. Biogeogr., 21, 75-84.

Erwin, R. M. (1983), Feeding habitats of nesting wading birds: spatial use and social influences. Auk, 100, 960-970.

Erwin, R. M. (1985), Foraging decisions, patch use, and seasonality in egrets (Aves: Ciconiiformes). Ecology, 66 : (3), 837-844.

Fasola, M. (1994), Opportunistic use of foraging resources by heron communities in southern Europe. Ecography, 17, 113-123.

Frederick, P. C. and Bildstein, K. L. (1992), Foraging ecology of seven species of neotropical ibises (Threskiornithidae) during the dry season in the Llanos of Venezuela. Wilson Bull., 104 : (1), 1-21.

Gaines, K. F.; Bryan Jr., A. L. e Dixon, P. M. (2000), The effects of drought on foraging habitat selection of breeding wood storks in coastal Georgia. Colon. Waterbirds, 23 : (1), 64-73.

Gaines, K. F.; Bryan Jr, A. L.; Dixon, P. M. and Harris, M. J. (1998), Foraging habitat use by wood storks nesting in the coastal zone of Georgia, USA. Colon. Waterbirds, 21 : (1), 43-52.

Gawlik, D. E. (2002), The effects of prey availability on the numerical response of wading birds. Ecol. Monogr., 72 : (3), 329-346.

González, J. A. (1996), Densidad y dinamica espaciotemporal de las poblaciones de cigüeñas (Ciconiidae) en los Llanos inundables de Venezuela. Orn. Neotrop., 7, 177-183.

González, J. A. (1997), Seasonal variation in the foraging ecology of the wood stork in the southern Llanos of Venezuela. Condor, 99, 671-680. 
Júlio Jr., H. F.; Petry, A. C.; Russo, M. R. and Gomes, L. C. (2000), Ictiofauna. In: Agostinho, A. A.; Thomaz, S. M.; Nakatani, K.; Júlio Jr., H. F.; Antônio, R. R.; Luz, K. D. G.; Zavadski, F. C. and Pereira, J. L. L. (Eds.). A planície alagável do alto rio Paraná: estrutura e processos ambientais. Maringá: Relatório Técnico PELD/CNPq. pp. 131-147.

Kushlan, J. A. (1976a), Feeding behavior of North American herons. Auk, 93, 86-94.

Kushlan, J. A. (1976b), Wading bird predation in a seasonally fluctuating pond. Auk, 93, 464-476.

Kushlan, J. A. (1978), Feeding ecology of wading birds. In: Sprunt, A.; Ogden, J. C. and Winckler, S. (Eds.). Wading birds. New York: Natl. Audubon Soc. pp. 249-297.

Kushlan, J. A. (1981), Resource use strategies of wading birds. Wilson Bull., 93 : (2), 145-163.

Kushlan, J. A.; Morales, G. and Frohring, P. C. (1985), Foraging niche relations of wading birds in tropical wet savannas. In: Buckley, P. A.; Foster, M. S.; Morton, E. S.; Ridgely, R. S. and Buckley, F. G. (Eds.). Neotropical ornithology. Washington: The American Ornithologists Union. pp. 663-682.

Loftus, W. F. and Eklund, A. (1994), Long-term dynamics of an Everglades small-fish assemblage. In: Davis, S. M. and Ogden, J. C. (Eds.). Everglades: the ecosystem and its restoration. Delray Beach, Florida: St. Lucie Press. pp. 461-484.

Maack, R. (1981), Geografia física do Estado do Paraná. Secretaria da Cultura e do Esporte, Curitiba.

Maccarone, A. D. and Brzorad, J. N. (1998), The use of foraging habitats by wading birds seven years after the occurrence of major oil spills. Colon. Waterbirds, 21 : (3), 367-374.

Magurran, A. E. (1988), Ecological diversity and its measurement. London: Croom Helm.

Master, T. L.; Frankel, M. and Russell, M. (1993), Benefits of foraging in mixed-species wader aggregations in a southern New Jersey saltmarsh. Colon. Waterbirds, 16 : (2), 149-157.

Paszkowski, C. A. and Tonn, W. M. (2000), Effects of lake size, environment, and fish assemblage on species richness of aquatic birds. Verh. Internat. Verein. Limnol., 27, 178-182.

Powell, G. V. N. (1987), Habitat use by wading birds in a subtropical estuary: implications of hydrography. Auk, 104, 740-749.

Russell, G. J.; Bass Jr., O. L. and Pimm, S. L. (2002), The effect of hydrological patterns and breedingseason flooding on the numbers and distribution of wading birds in Everglades National Park. Anim. Conserv., 5, 185-199.

Smith, J. P. (1997), Nesting season food habits of 4 species of herons and egrets at Lake Okeechobee, Florida. Colon. Waterbirds, 20 : (2), 198-220.

Smith, R. B. and Breininger, D. R. (1995), Wading bird populations of the Kennedy Space Center. Bull. Mar. Sci., 57 : (1), 230-236.
Souza, M. C.; Cislinski, J. and Romagnolo, M. B. (1997), Levantamento florístico. In: A planície de inundação do alto rio Paraná: aspectos físicos, biológicos e socioeconômicos. A. E. A. M. Vazzoler; A. A. Agostinho and N. S. Hahn. EDUEM: Nupélia, Maringá, pp. 343-368.

Souza-Filho, E. E. and Stevaux, J. C. (2002), Locais de amostragem. In: A planície alagável do alto rio Paraná: estrutura e processos ambientais, ed. A. A. Agostinho; S. M. Thomaz; K. Nakatani; H. F. Júlio Jr.; R. R. Antônio; K. D. G. Luz; F. C. Zavadski and J. L. L. Pereira. Relatório Técnico PELD/CNPq, Maringá, pp.7-13.

Souza-Filho, E. E. and Stevaux, J. C. (1997), Geologia e geomorfologia do complexo rio Baía, Curutuba, Ivinheima. In: A planície de inundação do alto rio Paraná: aspectos físicos, biológicos e socioeconômicos, ed. A. E. A. M. Vazzoler; A. A. Agostinho and N. S. Hahn. EDUEM: Nupélia, Maringá, pp. 3-46.

Stevaux, J. C.; Souza-Filho, E. E. and Jabur, I. C. (1997), A história quaternária do rio Paraná em seu alto curso. In: Vazzoler, A. E. A. M.; Agostinho, A. A. and Hahn, N. S. (Eds.). A planície de inundação do alto rio Paraná: aspectos físicos, biológicos e socioeconômicos. Maringá: EDUEM. pp. 47-72.

Strong, A. M.; Bancroft, G. T. and Jewell, S. D. (1997), Hydrological constraints on tricolored heron and snowy egret resource use. Condor, 99, 894-905.

Suter, W. (1994), Overwintering waterfowl on Swiss lakes: how are abundance and species richness influenced by trophic status and lake morphology? Hydrobiologia, 279/280, 1-14.

Thomaz, S. M.; Roberto, M. C. and Bini, L. M. (1997), Caracterização limnológica dos ambientes aquáticos e influência dos níveis fluviométricos. In: Vazzoler, A. E. A. M.; Agostinho, A. A. and Hahn, N. S. (Eds.). A planície de inundação do alto rio Paraná: aspectos físicos, biológicos e socioeconômicos. Maringá: EDUEM. pp. 73-102.

Vazzoler, A. E. A. M.; Agostinho, A. A. and Hahn, N. S. (1997a), A planície de inundação do alto rio Paraná: aspectos físicos, biológicos e socioeconômicos. Maringá: EDUEM.

Vazzoler, A. E. A. M.; Suzuki, H. I.; Marques, E. E. and Lizama, M. L. A. P. (1997b), Primeira maturação gonadal, período e área de reprodução. In: Vazzoler, A. E. A. M.; Agostinho, A. A. and Hahn, N. S. (Eds.). A planície de inundação do alto rio Paraná: aspectos físicos, biológicos e socioeconômicos. Maringá: EDUEM. pp. 249-265.

Willard, D. E. (1985), Comparative feeding ecology of twenty-two tropical piscivores. In: Buckley, P. A.; Foster, M. S.; Morton, E. S.; Ridgely, R. S. and Buckley,F. G. (Eds.). Neotropical ornithology. Washington: The American Ornithologists Union. pp. 788-797. 
Willis, E. O. (1995), Black versus white waterbird colonies (Aves) in the Bolivian-Brazilian Pantanal. Iheringia, 78, 95-97.

Wong, L. C.; Corlett, R. T.; Young, L. and Lee, J. S. Y. (2001), Utilization of wetlands by ardeids in Starling Inlet, Hong Kong: a year-round study and a comparison between the census and flight-line methods. Waterbirds, 24 : (1), 153-160.

Young, L. and Chan, G. (1997), The significance of drained fish ponds for wintering waterbirds at the Mai Po marshes, Hong Kong. Ibis, 139 : (4), 694-698.

Received: June 28, 2004;

Revised: April 18, 2005;

Accepted: February 09, 2006. 